\title{
Influence of Using Different Light Curing Devices on the Microhardness of a Bulk-Fill Resin
}

\section{Influência da Utilização de Diferentes Aparelhos Fotopolimerizadores na Microdureza de uma Resina Bulk Fill}

\author{
João Marcos Carvalho Silvaa; Alina Barreto de Negreiros Ribeiro Silva ${ }^{\mathrm{b}}$; Ayrton de Sá Brandim; \\ Mila Oliveira Santos Viana ${ }^{\mathrm{a}}$ \\ ${ }^{a}$ Centro Universitário UniFacid, Dentistry Course. PI, Brazil. E

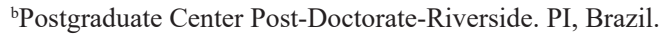 \\ ${ }^{c}$ Federal Institute of Education, Science and Technology of Piaui, Research, Postgraduate and Innovation Board. PI, Brazil. \\ *E-mail address: alina.barreto@hotmail.com
}

\begin{abstract}
Bulk Fill resins are a class of resin composites widely used today and have low polymerization shrinkage. However, these materials need an appropriate light curing technique to have good physical and mechanical properties. The objective of this study was to evaluate the surface microhardness of Bulk Fill resins after their light-curing with two types of high- power light-curing devices, using three techniques. 30 specimens were made with a nanoparticulate composite resin Opus Bulk Fill (FGM) and were divided into three groups according to the device and intensity of light curing: Group 1 - light curing with the Emitter B device (Schuster); Group 2 - light curing with the Valo device (Ultradent) at Standard power; and Group 3 - light curing with the Valo device at high power. Higher values of top surface microhardness were observed in Group 3 (microhardness $=53.6 \mu \mathrm{m})$, followed by Group $2($ microhardness $=52.1 \mu \mathrm{m})$ and Group $1($ microhardness $=33.1 \mu \mathrm{m})$, with $\mathrm{p}$ values $<0.05$. Therefore, the Valo light curing unit, in the two powers used, provided greater surface microhardness for the studied specimens.
\end{abstract}

Keywords: Polymerization. Composite Resins. Hardness Tests. Dentistry.

\section{Resumo}

Resinas Bulk Fill são uma classe de compósitos resinosos bastante utilizados atualmente e apresentam baixa contração de polimerização. Entretanto, esses materiais necessitam de uma adequada técnica de fotopolimerização para que apresentem boas propriedades fisicas e mecânicas. O objetivo deste estudo foi avaliar a microdureza superficial de resinas Bulk Fill fotopolimerizadas com dois tipos de aparelhos fotopolimerizadores de alta potência, em três técnicas de utilização. Foram confeccionados 30 corpos de prova com uma resina composta nanoparticulada Opus Bulk Fill (FGM) e divididos em três grupos de acordo com o aparelho e intensidade de fotopolimerização: Grupo 1 fotopolimerização com o aparelho Emitter B. (Schuster), Grupo 2 - fotopolimerização com o aparelho Valo (Ultradent) na potência Standard, Grupo 3 - fotopolimerização com o aparelho Valo em alta potência, posteriormente foi realizado o teste de microdureza de Vickers na região superficial de topo dos corpos de prova. Observou-se maiores valores de microdureza superficial de topo no Grupo 3 (microdureza= 53,6 $\mu \mathrm{m}$ ), seguido pelo Grupo 2 (microdureza= 52,1 $\mu \mathrm{m}$ ) e Grupo 1 (microdureza= 33,1 $\mu \mathrm{m}$ ), com valores de $p<0,05$. Assim sendo, o aparelho fotopolimerizador Valo, nas duas potências utilizadas, forneceu maior microdureza superficial para os corpos de prova estudados.

Palavras-chave: Polimerização. Resinas Compostas. Testes de Dureza. Odontologia.

\section{Introduction}

Direct restorative materials have been widely used in contemporary dentistry due to a growing esthetic search by patients $^{1}$. Thus, composite resins are restorative materials that have evolved over the years and are well indicated for certain treatments, presenting simplified protocols of chemical adhesion to dental structure. However, composite resins still have limitations regarding their indication, since they present polymerization contraction, promoting tensions in the toothrestoration interface, causing the appearance of cracks and infiltrations, leading to the failure of restorative treatment ${ }^{2,3}$.

Polymerization contraction takes place through the phenomenon of shortening of the monomer chains for the polymers formation. Therefore, the incremental insertion and photo- polymerization technique of portions of a maximum 2 $\mathrm{mm}$ thickness is necessary, avoiding the occurrence of higher tensions and/or under-polymerization in the restoration deeper layers ${ }^{4}$. In view of that, extensive cavities need a longer clinical time to be restored, which may cause discomfort to the patient, in addition to increasing the risk of contamination of the restorative protocol and incorporation of bubbles ${ }^{5}$.

In view of the need to improve the properties of composite resins in order to enable better and more efficient clinical performance, Bulk Fill resins arouse on the market ${ }^{6}$. This class of composites allows the use of the material in a single increment of up to $5 \mathrm{~mm}$ thick, since they present greater translucency, allowing the light beams to penetrate throughout the depth of the material, in addition to presenting low polymerization contraction, enabling lower tension values in the tooth-restoration interface ${ }^{7}$.

Nevertheless, the ideal physical and mechanical properties of Bulk Fill resinous composites are closely related to a correct degree of photopolymerization ${ }^{8}$. Thus, their mechanical 
Continuation

properties may be potentiated or decreased depending on the type of light-curing apparatus, the emitted wavelength, the time and/or intensity of photo-polymerization and the temperature released during polymerization. Thus, the more efficient the polymerization of Bulk Fill resins, the better their clinical performance and the longevity of restorative treatment ${ }^{9-11}$.

Thus, better clinical results are obtained when there is a correct indication of the restorative material and the protocols of use are followed, in addition to performing a correct photo-polymerization that provides the restoration with better mechanical properties, such as microhardness. Thus, the objective of the present study was to evaluate the surface microhardness of light-cured Bulk Fill resins with different types of high-power light-curing apparatus.

\section{Material and Methods}

\subsection{Experimental design}

A nanoparticle compound resin Opus Bulk Fill (FGM) was used to make 30 specimens. The specimens were divided into three groups. Each group was photoactivated with a type of light emitting diode (LED) apparatus, namely, high-power light curing device Emitter B. (Schuster) and high-power light curing device Valo (Ultradent) at the standard and high power. The results were obtained by Vickers' microhardness test on the top surface area of the specimens.

\subsection{Materials used}

To determine the microhardness value of the composite resin in relation to the type of light curing apparatus and intensity used, a fluid filling composite resin Opus Bulk Fill (FGM), in A2 color, with chemical composition listed in Table 1, was selected. In addition, two high-power LED light curing devices were selected, following the manufacturer's recommendations for use listed in Table 2.

Table 1 - Technical description of the Bulk Fill resin by the manufacturer

\begin{tabular}{|l|l|}
\hline Composite Resin & Opus Bulk Fill, color A2. \\
\hline Classification & Bulk Fill \\
\hline Manufacturer & FGM, Joinville, SC, Brazil \\
\hline $\begin{array}{l}\text { Composition - Organic } \\
\text { matrix }\end{array}$ & $\begin{array}{l}\text { AUDMA, stabilizers, co- } \\
\text { initiators and light-curing } \\
\text { materials }\end{array}$ \\
\hline $\begin{array}{l}\text { Composition - Inorganic } \\
\text { matrix }\end{array}$ & $\begin{array}{l}\text { Silicon dioxide, stabilizers and } \\
\text { pigments }\end{array}$ \\
\hline Load volume and weight (\%) & $\begin{array}{l}76.5 \% \text { in weight and 58.4\% in } \\
\text { volume }\end{array}$ \\
\hline
\end{tabular}

Table 2 - Technical description of the light-curing apparatus according to the manufacturers

\begin{tabular}{|c|l|l|l|}
\hline $\begin{array}{c}\text { Light-curing } \\
\text { apparatus }\end{array}$ & Emitter B & \multicolumn{1}{|c|}{$\begin{array}{c}\text { Valo - } \\
\text { Standard }\end{array}$} & $\begin{array}{c}\text { Valo - High } \\
\text { power }\end{array}$ \\
\hline \multirow{3}{*}{ Manufacturer } & $\begin{array}{l}\text { S c h u s t e r, } \\
\text { Santa Maria, } \\
\text { RS, Brazil }\end{array}$ & $\begin{array}{l}\text { Und traiat e n t, }, \\
\text { SP, Brazil }\end{array}$ & $\begin{array}{l}\text { U l trad ent }, \\
\text { Indaiatuba, } \\
\text { SP, Brazil }\end{array}$ \\
\hline
\end{tabular}

\begin{tabular}{|l|l|l|l|}
\hline Wavelength & $420-480 \mathrm{~nm}$ & $420-480 \mathrm{~nm}$ & $420-480 \mathrm{~nm}$ \\
\hline Light power & $1250 \mathrm{~mW} / \mathrm{cm}^{2}$ & $1000 \mathrm{~mW} / \mathrm{cm}^{2}$ & $1400 \mathrm{~mW} / \mathrm{cm}^{2}$ \\
\hline Use technique & $30 \mathrm{~s}$ & $\begin{array}{l}\text { Initial: } 1 \text { time } \\
\text { of } 10 \mathrm{~s} \\
\text { Final: } 2 \text { times } \\
\text { of } 10 \mathrm{~s}\end{array}$ & $\begin{array}{l}\text { Initial: } 2 \text { times } \\
\text { of } 4 \mathrm{~s} \\
\text { Final: } 3 \text { times } \\
\text { of } 4 \mathrm{~s}\end{array}$ \\
\hline
\end{tabular}

Legend: $\mathrm{nm}$ (nanometers), $\mathrm{mW} / \mathrm{cm}^{2}$ (milliwatt per square centimeter), $\mathrm{s}$ (seconds).

Source: Research data.

Bulk Fill composite resins have been widely used in the dental clinic, and so that they have a good clinical performance, they should be adequately light-cured, with powerful light-curing devices and emit uniform light beams, with adequate time protocols, so that their physical and mechanical properties are enhanced. Thus justifying the use of the listed materials.

\subsection{Preparing the specimens}

For the specimens preparation, a low rigidity silicone matrix OMT 189 (Odeme Dental Research, Luzern, SC) was used in a pink color and a rectangular shape with three perforations of $5 \mathrm{~mm}$ depth and separated of each other by 5 $\mathrm{mm}$ distance.

The insertion of the composite resin inside the perforations was made with the aid of a titanium insertion spatula number 5 (Millennium - Golgram, São Caetano do Sul, SP) in single increment, adapted and duly condensed in the rubber matrix, later, a clear polyester strip and glass plate were placed, applying light pressure to the rubber matrix to promote greater surface flatness and no bubbles. The distance between the end piece of the light-curing apparatus in each group was standardized and the compound resin was cure-lighted according to the technical standards of each manufacturer, as listed in Table 2. After setting the material, the specimens were removed from the matrix, where the top surface was standardized and with the aid of a blade of scalpel number 15 , the excesses were removed to promote a better surface flatness.

The specimens were identified and stored in a container containing distilled water at $37 \mathrm{C}$ for 24 hours until they were submitted to Vickers' microhardness test.

\subsection{Experimental groups}

The 30 specimens were divided into 3 groups according to the type of photo-polymerization intensity applied by the 2 types of apparatuses. Group 1: Photo-activation with the Emitter B apparatus in high power; Group 2: Photo-activation with Valo apparatus at Standard Power; Group 3: Photoactivation with the apparatus Valo in high power.

\subsection{Microhardness test}

Before starting the microhardness test, the specimens were measured with a digital pachymeter Absolute Digimatic (Mitutoyo Sul Americana, Santo Amaro, SP) to obtain their 
dimensions. Subsequently, to perform the microhardness test, a HMV 2000 micro durometer (Shimadzu, Baurueri, SP) was used with Vickers type penetrator, with a static load of $50 \mathrm{~g}$ for $45 \mathrm{~s} .3$ indentations were performed on the center surface of the top of the specimens.

\subsection{Statistical Analysis}

After obtaining the surface microhardness values, the means and standard deviation of each group were calculated, the variables used were surface microhardness, diameter of the specimens and depth. The variables were treated in the Statistical Package for the Social Sciences 20.0 (SPSS, Chicago, IL, USA), where it was observed that the variables followed the non-normality pattern with a $\mathrm{p}$ value $<0.05$. Thus, the test selected for the associations was Kruskall-Wallis, considering significant values of $\mathrm{p}<0.05$.

\section{Results and Discussion}

The results obtained consisted of a total of 90 Vickers microhardness values, performed at the central top of the specimens, in which 30 edentations were performed in each group studied. Group 1 presented the lowest superficial microhardness compared to groups 2 and 3, as shown in Figure 1.
Figure 1 - Distribution of microhardness values in 3 different groups with values in micrometers $(\mu \mathrm{m})$

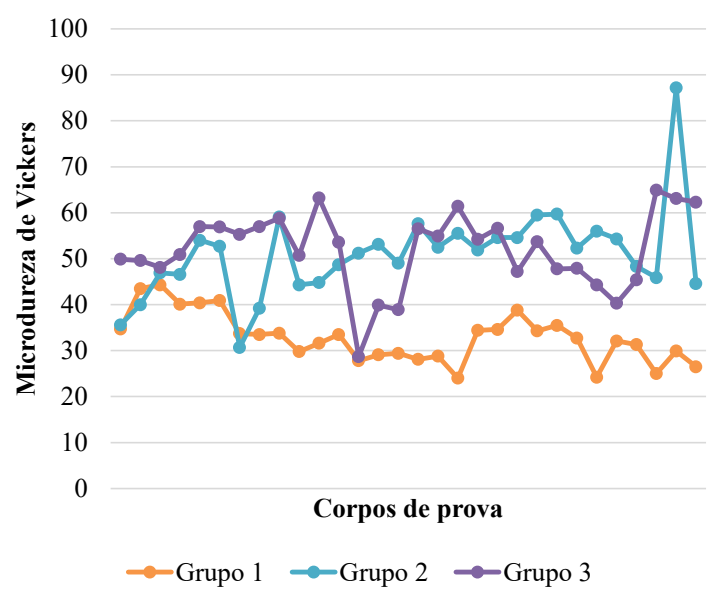

Source: Research data.

Concerning the type of light-curing apparatus and its application intensity, higher values of top surface microhardness were observed in Group 3 (microhardness = $53.6 \mu \mathrm{m})$, followed by Group 2 (microhardness $=52.1 \mu \mathrm{m})$ and Group 1 (microhardness $=33.1 \mu \mathrm{m})$, with $\mathrm{p}$ values $<0.05$ In addition, it was observed that there was an association between the polymerization depth among the 3 groups studied, where group 3 presented greater depth than groups 2 and 3, with $\mathrm{p}>0.05$, as listed in Table 3 .

Table 3 - Kruskall-Wallis test. Association among the 3 groups regarding surface microhardness, diameter and polymerization depth

\begin{tabular}{|l|c|c|c|c|}
\hline \multirow{2}{*}{ Tests } & Group 1 & Group 2 & Group 3 & p-Value* \\
\cline { 2 - 5 } & $\begin{array}{c}\text { Median } \\
\text { (minimum }- \text { maximum } \\
\text { value })\end{array}$ & $\begin{array}{c}\text { Median } \\
\text { (minimum - maximum } \\
\text { value) }\end{array}$ & $\begin{array}{c}\text { Median } \\
\text { (minimum - maximum } \\
\text { value) }\end{array}$ & $\begin{array}{c}53.6 \mu \mathrm{m} \\
(28.7-64.9) \mathrm{b}\end{array}$ \\
\hline Microhardness & $\begin{array}{c}33.1 \mu \mathrm{m} \\
(24.0-44.3) \mathrm{a}\end{array}$ & $\begin{array}{c}52.1 \mu \mathrm{m} \\
(30.7-87.2) \mathrm{a}\end{array}$ & $\begin{array}{c}4.9 \mathrm{~cm} \\
(4.8-5.0) \mathrm{c}\end{array}$ & $<0.001$ \\
\hline Diameter & $\begin{array}{c}5.0 \mathrm{~cm} \\
(4.9-5.2) \mathrm{a}\end{array}$ & $\begin{array}{c}4.9 \mathrm{~cm} \\
(4.5-4.9) \mathrm{b}\end{array}$ & $\begin{array}{c}4.2 \mathrm{~cm} \\
(4.0-4.5) \mathrm{c}\end{array}$ & $<0.001$ \\
\hline Depth & $\begin{array}{c}4.1 \mathrm{~cm} \\
(3.9-4.3) \mathrm{cm}\end{array}$ & $\begin{array}{c}3.9 \mathrm{~cm} \\
(3.6-4.3) \mathrm{b}\end{array}$ & $<0.001$ \\
\hline
\end{tabular}

Legend: micrometers $(\mu \mathrm{m})$; centimeters $(\mathrm{cm}) ; \mathrm{a}, \mathrm{b}, \mathrm{c}=$ different letters indicate a significant association among the variables.

Source: Research data.

The resinous composites have evolved over the years since their appearance, presenting better physical and mechanical properties. Currently, there are resinous composites that can be used in a single increment of up to $5 \mathrm{~mm}$ thick, presenting low polymerization contraction of the resinous monomers and excellent mechanical performance after the setting. However, in order to preserve the mechanical properties of these materials, it is essential that adequate light-curing of the restoration be performed ${ }^{7}$.

Light-curing units emit a bluish light, with wavelengths ranging from 420 to $480 \mathrm{~nm}$. This wavelength is ideal for the initiation of camphor quinone, initiator of the photopolymerization of compound resins. Furthermore, light intensity and light emission power are also determining factors for adequate polymerization of monomeric chains ${ }^{9,10}$.

So that proper photo-polymerization is achieved of Bulk
Fill resins, since they are used in thicker increments, lightcuring devices with a minimum power from 800 to $1000 \mathrm{~mW} /$ $\mathrm{cm}^{2}$ must be used, since this application intensity is adequate for light beams to penetrate the entire depth of the restoration, promoting a higher degree of polymerization ${ }^{9-11}$.

These evidences were confirmed when the analysis of Vickers' surface microhardness values of the specimens prepared and light-cured with different apparatuses and light emission intensities were performed. Just as in previous studies $^{12-15}$. It was evidenced that the group light-cured with the Valo apparatus at high power $(1400 \mathrm{~mW} / \mathrm{cm} 2)$ showed higher values of superficial microhardness, followed by the group light-cured with the Valo apparatus at standard power $(1000 \mathrm{~mW} / \mathrm{cm} 2)$ and the Emitter B apparatus at high power (1250 mW/cm2).

However, it was observed that the Valo light-curing 
apparatus, regardless of its power used, presented better values of surface top microhardness, when compared to Emitter B. this fact was also observed in previous studies comparing microhardness and/or monomeric conversion degree with the use of Valo light-curing apparatus and other apparatuses ${ }^{12-15}$.

The following results can be explained by the anatomy of the light-curing apparatus. Valo apparatus has its active light emitting tip with a larger diameter, in addition to the apparatus emitting uniform collimated luminous beams throughout the length and depth of the restorative material, thus, it can promote a higher degree of monomeric conversion and potentiate the physical and mechanical properties of resinous composites. Whereas active light-emitting tip of Emitter B device, however, is smaller in diameter, and its light beam emission may not be collimated and uniform, impairing the mechanical performance of the resin material ${ }^{13}$. In addition, several factors should be taken into consideration, such as the oscillation of the light beam wavelength emission and duration of the application time, which may negatively affect the degree of the resin materials polymerization.

\section{Conclusion}

The high-power Valo light-curing apparatus showed better polymerization of the Bulk Fill composite resin used, observed by Vickers' surface microhardness test results in the specimens. However, similar values of superficial microhardness were obtained with the use of the same lightcuring device in standard power. Therefore, the proper use of Valo curing apparatus may potentiate the mechanical properties of Bulk Fill composite resins, acting synergistically for the success of restorative treatments.

\section{References}

1. Hirata R, Clozza E, Giannini M, Farrokhmanesh E, Janal M, Tovar N, et al. Shrinkage assessment of low shrinkage composites using micro-computed tomography. J Biomed Mater Res - Part B Appl Biomater 2015;103(4):798-806. doi: https://doi.org/10.1002/jbm.b.33258

2. Pitta Lopes J, Catalão F, Barragán G, Portugal J, ArantesOliveira S. Influence of several occlusal matrix in the resin composite light curing: Knoop microhardness test. Rev Port Estomatol Med Dent Cir Maxilofac 2013;54(4):203-9. doi: https://doi.org/10.1016/j.rpemd.2013.10.001

3. Ferracane JL. Resin-based composite performance: are there some things we can't predict? Dent Mater 2013;29(1):51-8. doi: http://dx.doi.org/10.1016/j.dental.2012.06.013

4. Flury S, Hayoz S, Peutzfeldt A, Hüsler J, Lussi A. Depth of cure of resin composites: Is the ISO 4049 method suitable for bulk fill materials? Dent Mater 2012;28(5):521-8. doi: http:// dx.doi.org/10.1016/j.dental.2012.02.002

5. Fasbinder D, Dennison J, Heys D, Neiva G. A Clinical Evaluation of Chairside Lithium Disilicate CAD/CAM Crowns. J Am Dent Assoc 2010;141:10-4. doi: https://doi. org/10.14219/jada.archive.2010.0355

6. Ilie N, Bucuta S, Draenert M. Bulk-fill resin-based composites: An in vitro assessment of their mechanical performance. Oper Dent 2013;38(6):618-25. doi: https://doi. org/10.2341/12-395-1

7. Kim RJY, Kim YJ, Choi NS, Lee IB. Polymerization shrinkage, modulus, and shrinkage stress related to toothrestoration interfacial debonding in bulk-fill composites. J Dent 2015;43(4):430-9. doi: http://dx.doi.org/10.1016/j. jdent.2015.02.002

8. El-Safty S, Silikas N, Watts DC. Creep deformation of restorative resin-composites intended for bulk-fill placement. Dent Mater 2012;28(8):928-35. doi: http://dx.doi. org/10.1016/j.dental.2012.04.038

9. Ilie N, Keßler A, Durner J. Influence of various irradiation processes on the mechanical properties and polymerisation kinetics of bulk-fill resin based composites. J Dent 2013;41(8):695-702. doi: https://doi.org/10.1016/j. jdent.2013.05.008

10. Bucuta S, Ilie N. Light transmittance and micro-mechanical properties of bulk fill vs. conventional resin based composites. Clin Oral Investig 2014;18(8):1991-2000. doi: https://doi. org/10.1007/s00784-013-1177-y

11. Fronza BM, Ayres APA, Pacheco RR, Rueggeberg FA, Dias CTS, Giannini M. Characterization of inorganic filler content, mechanical properties, and light transmission of bulk-fill resin composites. Oper Dent 2017;42(4):445-55. doi: https:// doi.org/10.2341/16-024-L

12. Sahadi BO, Price RB, André CB, Sebold M, Bermejo GN, Palma-Dibb RG, et al. Multiple-peak and single-peak dental curing lights comparison on the wear resistance of bulk-fill composites. Braz Oral Res 2018;32:e122. doi: https://doi. org/10.1590/1807-3107bor-2018.vol32.0122

13. Shimokawa CAK, Turbino ML, Giannini M, Braga RR, Price RB. Effect of light curing units on the polymerization of bulk fill resin-based composites. Dent Mater 2018;34(8):1211-21. doi: https://doi.org/10.1016/j.dental.2018.05.002

14. Rocha MG, De Oliveira DCRS, Correa IC, Correr-Sobrinho L, Sinhoreti MAC, Ferracane JL, et al. Light-emitting diode beam profile and spectral output influence on the degree of conversion of bulk fill composites. Oper Dent 2017;42(4):41827. doi: https://doi.org/10.2341/16-164-L

15. Sharma A, Aggarwa N, Rastogi S, Choudhury R, TEripathi $\mathrm{S}$. Effectiveness of platelet-rich fibrin in the management of pain and delayed wound healing. Eur J Dent 2017;11(4):1925. doi: https://doi.org/10.4103/ejd.ejd_346_16. 